\title{
Specific Uses of Angels, Devils, Heaven and Hell in Advertising
}

\author{
Costin Popescu
}

Faculty of Letters, University of Bucharest, Romania

Copyright $(2018$ by authors, all rights reserved. Authors agree that this article remains permanently open access under the terms of the Creative Commons Attribution License 4.0 International License

\begin{abstract}
Advertising looks into every field of the social practice for symbols that, associated to products, help it sell them better. It could not miss the religious symbols. This article examines changes in representations and meanings of angels, devils, Heaven, and Hell confirmed or brought about by advertisements. As the literature indicates, the amount of commercial messages using religious themes (especially the amount of advertisements using the four themes) is small. The corpus was created by browsing the 2005 and 2015 issues of four glossy magazines and by collecting advertisements from different media: news magazines, magazines for women, important producers' sites, advertising sites, out-of-home. The componential analysis and the visual semiotics offered the ways to examine the corpus; readings from scientific literature on the four religious themes and a questionnaire whose respondents were graduate students of the Consulting and Expertise in Advertising program, University of Bucharest, helped complete the research. The distinctive features of angels, devils, Heaven, and Hell, as they were presented by researchers of the christian faith, are compared to features that graduate students, part of popular culture, and advertising ascribe them. Angels and devils have become symbols of high intensity experiences, meant to improve humans' existential condition. Every space where an individual invests subjective energy intended to raise him / her from monotonous life can become Heaven. Hell is matter for irony (we read Hell to understand Heaven) or instrument of blackmails (who does not use the products arrives there). Given the small number of advertisements in the corpus, this research can be qualified as an attempt to answer a difficult question: how to investigate more attentively a process, the use of religious themes in advertising, that everybody notice, but whose breadth and effects are not yet sufficiently determined.
\end{abstract}

Keywords Visual Semiotics, Componential Analysis, Angels, Devils, Heaven, Hell

\section{Introduction}

The very way books on marketing define the product shows how advertising, in order to sell what it is asked to sell, is inclined to search in every field of social practice for appeals:

A product is not just a physical object; it is a bundle of benefits or values that satisfies the needs of consumers. The needs may be purely functional, or they may include social and psychological benefits (...) For many products, strong symbolic features and social and psychological meaning may be more important than functional utility. (G. E. Belch, M. A. Belch, 2007: 59)

Every product has two sides: practical-utilitarian and symbolic. Advertising is in need of symbolic stimuli strong enough to determine the consumers to buy the products associated with them. The religion can produce such stimuli.

The object of faith (deeds and sayings pertaining to supernatural beings or elevated-to-supernaturality beings and having an exemplar meaning for mankind, as long as they indicate the laws according to which the multi-leveled world is ordered and functions (Eliade, 1993: 23, 26)) has become object for other activities too, cognitive or practical, from theology (as study of faith) to advertising action. How do angels and devils, Heaven, and Hell appear in advertisements?

\section{Review of Literature; Method}

Jérôme Cottin and Rémi Walbaum (1997) presented three big areas of the Christian thinking, each of them divisible in several segments, where advertising looks for inspiration: God in the heavens, Jesus of Nazareth, Christ and the Cross. The chapter dedicated to Heaven and to the deculpabilization of humans examines three advertisements. In all, there are 138 biblical references; the period during which the advertisements from the corpus 
were spread is not mentioned.

Maguire and Weatherby (1988) defined "religious images" listing several criteria, to be accomplished together or separately; these images show: - places linked to religious practices (worship, etc.), - places with historical meanings for believers, - individuals whose aspect or actions define them as representative for a religious faith, - historical events or groups of humans recognizable as pertaining to a specific religious tradition, individuals with a precisely defined religious behaviour (worship, meditation). The authors recorded forty hours of programs broadcasted by networks and used the content analysis to examine the 16 commercials with religious images from a general total of 797 ( 2 per cent).

Ray Clifton Moore (2005) published a research on the 2003 issues of Time, Newsweek, and US News and World Report. Using the criteria of Maguire and Weatherby, Moore identified 51 advertisements with religious images: 1.13 per cent of the total (4.533 advertisements). He used the content analysis to examine them.

Recording in July 2005 programs totalizing two to five hours a day aired by eight important American networks: ABC, FOX, FAM, MTV, ESPN, CBS, CNN, NBC (a random draw was used to determine the date reserved to each network), G. A. Weatherby and Jean Pugh (2008) found that 1.499 commercials had been broadcasted and that only 51 (in fact, 30 , because some commercials had been aired several times) had had religious content. 2 per cent.

Mallia conducted in 2009 a qualitative study (content and textual analysis) meant to determine the offensive potential of commercials using religious themes. She concluded that it is convenient for advertising to attract people's attention on products by shocking, and that offense is the simplest way to shock. (Mallia, 2009: 174) The offenses come from a perceived incongruence between religious referent and product or the violation of religious belief or dogma. (Mallia, 2009: 184-185)

Reviewing the literature, Nardella (2012) mentions that some efforts to create corpuses were "non systematic". Potel collected advertisements using religion spread between 1966 and 1980 by print, radio, tv, and billboards and tried to classify christian symbols. Lugrin and Molla collected more than 200 advertisements presented during several decades in different countries (the period and the countries are not indicated). Nardella himself collected 607 advertisements on religious themes from those diffused in 1989, 1993, 1997, 2001, 2005, 2009, in October and December (two issues per month) in 224 issues by 11 weeklies (news magazines, family magazines, womens' magazines, and supplements (among them, some for women)).

The figures are not impressive, even if the Italian researcher listed themes (Jesus and the Cross, the Lord, the saints, Heaven, sacred monuments, the Temptation, the Sin, etc.) seeming to suggest something else. How many advertisers attracted by such themes resist the temptation to show a manger in an advertisement presented in December? Nardella chose October and December because they are the months with the lowest and, respectively, the highest number of important religious feasts. The risk, for December, is that the advertisements will mainly use religious themes linked to the month's feasts: it is hard to believe that many advertisements with devils will be spread in December.

I browsed the 2005 and 2015 issues of the glossy magazines Unica, Viva, Cosmopolitan (the Romanian edition) and Elle (the Romanian edition). I considered the ten-year interval as sufficiently large to comprise possible changes of attitude in the use in advertisements of the four religious themes. There were 3,065 commercial messages, and angels and devils, Heaven and Hell were represented in only eight ( 0.26 per cent); in fact, there were four distinct prints, with eight appearances, a print for Philadelphia, cheese, and three for Angel, perfume. As long as the amount of religious themes was limited to four, the diminution of the percentage they represented from the totality of advertisements $(0,26$ per cent instead of 2 per cent in Weatherby and Pugh) is normal.

I think that, whatever the numeric results of such an investigation, when analyzing the collected data one has to consider that, as the audiences of such magazines are relatively similar and as the producers' interest for such audiences is high, these producers will show the same advertisements in several magazines. And that, given the span of time covered by a campaign, some advertisements will appear in several issues of the same magazine. Hence, a question: the total of advertisements concerns the total amount of appearances or the total amount of individual messages, with no attention payed to number of appearances? (If there had been 1,000 advertisements with a single appearance, instead of 3,065 advertisements, many with several appearances, the percentage of messages with angels, devils, Heaven, and Hell would have been 0.8 , instead of 0.26.) The way we arrive at the figures / percentages we need can be very deceptive.

I have also collected advertisements with angels, devils, Heaven, and Hell in the modality that Nardella called non systematic. Between 1995 and 2005 in large part, but up to the present too, I have collected advertisements from news weeklies (the Economist, l'Evénement du Jeudi, l'Express, le Figaro, Newsweek, le Nouvel Observateur, le Point, Time), from magazines for women (Biba, Cosmopolitan, Elle, Vogue), from the advertising site www.iqads.ro, from Lürzer's International Archives, I have browsed albums presenting Epica Awards, albums on the history of advertising, I have photographed outdoor advertising... I have gathered 48 advertisements, some of them pertaining to campaigns that used the four themes in all their messages, some others: to campaigns within which only a few messages / a message used the themes.

As I initially had found most advertisements in 
categories of print media, I continued my search by browsing the four aforementioned glossy magazines having circulations among the highest in Romania. And these magazines spread advertisements for brands in categories as perfume, cosmetics, cloths, phones, coffee, jewelry, watches, liqueur, bio food, medecines, private hospitals..., categories within which the products' connotative auras are very rich and the audiences very sensitive to appeals of personal value; so the possibility to resort to our themes is relatively high.

Clearly, we face here a ticklish methodological problem: the corpuses that can be collected from sources pertaining to a media category (news magazines) from a media class (magazines) are fragile; this fragility generates risks in the conclusions: elevated upon too insecure a basis, they become doubtful. When researches end up in this way: "this study (...) leaves numerous questions to be answered in future research" (Mallia), or in this way: we need "further study into the moods, strategies, and decisions of advertisers, especially as they relate to religion" (Moore), one must look for an explanation in the difficulties also met in the constitution of the corpuses.

For the time being, it is probably enough to purely and simply identify the main uses in advertising of the religious themes and the relationships between them. The simple manifestation of a use is now more important than, let's say, the manifestations' degree of recurrence; it shows that the theme is alive, active in the minds of people pertaining to a culture. The next step would suppose the emphasis on the integrated character of the religious themes' exploitation in advertising (and in society), an expression of the changes produced in the social condition of religion.

My main instruments were the componential analysis and the visual semiotics. I completed the research with the help of readings from scientific literature on the four religious themes and of a questionnaire whose respondents were graduate students of the Consulting and Expertise in Advertising program, University of Bucharest. To compare the most important distinctive features of angels, devils, Heaven, and Hell, as they were identified by researchers of the religious phenomenon, with the features that young people, members of popular culture, and advertisements ascribe them nowadays can be relevant for the way advertising understands the religion's functions in society. The questionnaire had 15 questions; they tried to provoke the respondents to tell which sources their knowledge has had on the angels, the devils, Heaven, and Hell, what they do remember from the information received from the sources, how they participate to the circulation in society of the information upon the four themes, what judgments they formulate upon the uses in advertising of angels, devils, Heaven, and Hell and upon the persuasive potential of the themes.

\section{Religious Contents and Their Actualization in the Commercial Messages}

\subsection{The Scientific Literature on the Four Religious Themes}

Let's consider the main conclusions of some researches in the theoretic field upon anges, devils, Heaven, and Hell (the amount of these researches is practically unlimited). In the traditional world, the sacred and the profane were to be kept separated. The access, periodic, to the transcendence was guaranteed by myth; Eliade sees it as a narrative of exemplar deeds accomplished by supernatural heroes; these deeds are capital because they show to mankind the order of the universe and tell them the meaning of their presence in the world. The supernaturality of those who accomplish these deeds gives them a paradigmatic character (Eliade, 1993: 17, 22-26). The author ends Aspects $d u$ mythe with a review of some ways to desacralize myths; we can conclude with Eliade that depriving the heroes of their supernaturality means making them humanlike and, consequently, contestable; depriving deeds of exemplarity means distroying the duty to submit to their pedagogic dimension. The several fields where Eliade remarks myth's desacralization (comics, detective stories...) prove that the creators of commercial messages have neither priority, nor monopoly with respect to our topic.

During the centuries, the theological reflection upon the angels retained some important features: the angels are non corporeal (but, according to some theologians, they have a body with a subtle, ethereal expression) (Andrei Pleşu, 2003: 47-48), "do not have divergent affects and put themselves above every form of sentimentalism" (but in the Scriptures there are angels who are happy and who cry) (92), are the paradigm of devotion (117), born from light, are witnesses of the beginning of the world, and their dominant state is euphoria (162), have an integrative, symbolic thinking (190), have a knowledge that comes from intellectual intuition (222) etc.

In an ordered world, the angels are placed on the highest level (the attribute of the pure existence in the creation plan: the mineral kingdom, the attribute of life: the vegetal kingdom, the attribute of animated life: the animal kingdom, the attribute of the spiritual life: the human kingdom, the attribute of the spiritual non corporeal life: the angelic kingdom) (45-46); as we all know, there are spheres of angels (Dionysius the Areopagite established three, each one with three categories of angels). Their fundamental function is to guide the mankind toward Salvation (86). For the ancient christians, the humans' vocation was defined as the possibility to participate in the angels' life, characterised by the possibility to see God (Bouyer, 1950: 43). 
The angels' corporeality inspired two main streams of thought: a) angels are immaterial, pure spirits, b) angels are made of a matter so subtle, that only people of holiness can see them. Stronger has seemed to be the faith that, immaterial, the angels could assume corporeal form: hence, the possibility to represent them. At the beginning, the Church firmly opposed to the angels' cult; then, as they became representable, the angels got the aspects of young eunuchs. Archangel Michael, chief commander of the Heaven's forces, was represented as a young eunuch; nothing to worry about, says Cyril Mango: it was a common practice to appoint generals who were eunuchs (Narsetes, one of the great generals of Justinian, was eunuch) (Cyril Mango, 1998: 178-180). And the saints' clothing reminded the one established for the great imperial ceremonies.

Henri-Irénée Marrou deplores the modern understanding of the devil; some identify him with the Evil, says he, thus giving him a symbolic dimension and separating him from" every living person"(Marrou, 1996: 496). According to Marrou, the Holy Fathers used the lexeme as an abbreviated but comprehensive form, as a convenient or emotional modality to present things by grouping all the infernal forces around their leader, in order to better oppose their role to that of our Savior, thus without denying the existence of other evil powers, of other evil spirits. (Marrou, 1996: 498)

The French scholar mentions a "scale of being-ness" having God, who is in the complete meaning of the term, at one end, and the non being at the other; between these ends there are different beings, more or less diminuated, according to their nearness to God (Marrou, 1996: 509-510).

From the numerous, and so finely interwoven, features of the devil, advertising selects two: a) evil supernatural beings (who move to and fro between earth and sky, as do good supernatural beings too), the devils have an individual concrete, even if invisible, existence (Marrou, 1996: 500, 502); b) they are beautiful (their divine origin guarantees that beauty). At the beginnings of christianity (for example at San Apollinarius, in Ravenna), the Satan was represented as a beautiful young man, with nimbus and wings, nobly wearing clothes nobly draped ("the falling, the decline that it has determined could not anihilate the angelic nature that defines his being" (Marrou, 1996: 499)). These two features are the object of advertising's efforts to ideologically remodel devils.

In the Middle Ages, the representations of devils as monsters were intended to frighten the sinners:

these representations are legitimate in the christian art only as ways to stage temptations, but not as ways to figure the Devil himself besides that temporary role of scarecrow. (Marrou, 1996: 505)

It is possible to establish a history of these variations in representation. In fact, this history is a succession of systems of equivalences between a set of expressive means and a set of "culturalized contents" (Eco, 1979: 204). According to the Italian semiotician, we succeed in understanding a given technical solution as the representation of a natural experience because there has been formed in us a codified system of expectations, which allows us to enter into the semantic world of the artist. Maybe an "iconic" solution is not conventional when it is proposed, but it becomes so step by step, the more its addressee becomes acquainted with it (...) Presuming that they exist, recognition codes (like any others) make provision for conveying pertinent features of the content. The recognizability of the iconic sign depends on the selection of these features. But the pertinent features must be expressed. Therefore there must exist an iconic code which establishes the equivalence between a certain graphic device and a pertinent feature of the recognition code. (Umberto Eco, 1979: 204-205, 206)

According to the medieval code of expectations, the devils had to be represented, for instance, a) by modifying the scheme of assembling the human body: they have eyes, mouth, nose... stuck on the belly (the technique corresponds to one of the visual transformations discussed in Traité du signe visuel by Groupe $\mu$ : déplacement (1992: 158-159)) or b) by associating, in a so-called ,irresolute entity", features of different types (interpénétration, Groupe $\mu, 1992: 274$ ), man and animal (to a human form were added horny structures specific to animals; this animalization corresponded to the idea of decline of creation). We all know the devils painted by Bosch.

Devils were considered as invisible; they could take any appearance too, they could disguise as they liked. We have seen that their very aspect was the effect of emphases put on different elements constituting faith (beings whose angelic nature cannot be rubbed off, beings whose horrorness ought to keep the believers away from $\sin .$. ). If we recall the process, mentionned by Marrou, that reduces the devil to a symbol of Evil, we see that what some could call content fuzziness, protean contents, etc. facilitates the infiltration into old meanings of new ones able to weaken them.

Heaven and Hell are common terms; we all seem to know their meanings, we all alter them little by little. We read in Genesis (2, 8-9) that God "planted a garden in Eden, in the east; and there he put the man whom he had formed. Out of the ground the Lord God made to grow every tree that is pleasant to the sight and good for food, the tree of life also in the midst of the garden, and the tree of the knowledge of good and evil." And, later $(2,15)$ : "The Lord God took the man and put him in the garden of Eden to till it and keep it." As Adam and Eve ate the fruit of the tree of the knowledge of good and evil, God sent them forth from the garden of Eden (saying to Adam: "By the sweat of your face you shall eat bread" $(3,19)$; in order to prevent that who He made of dust regain immortality, He "placed the cherubim, and a sword flaming and turning to guard the 
way to the tree of life." $(3,24)$

If, after Adam and Eve ate the fruit of knowledge, the ground outside the Eden is labored with sweat, it is easy to understand why humankind have the nostalgia for paradise (in one of the readings of Eliade's syntagm):

the wish to be always and without effort in the center of the world, of reality and of sacredness and, in brief, to naturally transcend the human condition and to regain the divine condition, a Christian would say: the condition before the Fall (Eliade, 1968: 322).

But Eliade remarks that another series of traditions insists upon the difficulty (and, hence, the merit) to reach the center of the world. The alternative is worth remembering; because later we read that the sacred space has a paradoxical dialectic: it is accessible and non accessible, it is, on the one hand, unique and transcendent, on the other hand, repeatable at will. Hence, the idea of "easy duplicates of the sacred space", especially of the "Center":

Their fabrication in series and on ever "lower", more and more "accessible" levels (thanks to multiple assimilations, everything can become a "center", a labyrinth, a symbol of immortality, etc.) certifies the reproduction we'd say mechanical of a single and same archetype in variants ever more "localized", ever "rougher". (Eliade, 1968: 323)

Jean Delumeau insists upon the unstable features of Paradise. For Pseudo-Basil, the Paradise was "a fertile land flowing with milk and honey, a land washed by rich waters, producing plenty of very tasteful fruit." (Delumeau, 1997:15) Philo, Origen, Ephrem the Syrian, who believed that the description of Paradise must be taken figuratively, could not attenuate the realistic (materialist) character of the faith in a safe and abundant life. Perhaps the tender light, the eternal spring, the suave perfumes, the celestial music from Paradise (Delumeau, 1977: 8) were for many too weak a compensation for the suffering in their earthly life; the difference between the real and the ideal worlds had to be pushed toward virulent oppositions (hence, land of cockaigne).

More than that: one of the ways to evoke Paradise has made it a pastoral scenery for love; for Milton, Adam and Eve were changing in Eden tender and chast kisses (Delumeau, 1997:13). Would the chasing away of Adam and Eve from Paradise have changed the quality of their kisses (from chast they have become guilty and sinful)?

We have been told that the sensorial pleasures lead to Hell; kisses must be announced as chast in order to find their place in Heaven. This dualism in interpretation (the same facts have different meanings according to their authors and to the places where they are accomplished) is constant: for example, the pagans' good deeds are sins, because "whatever is not of faith is $\sin$ "(Paul, Romans, 14, 23), the Christians' good deeds open the road to Paradise. Or, it is this very dualism, whatever radical it may seem, that encourages the slippings of meaning. How to formulate elements of the divine life (here, the reciprocal feeling nourished by Adam and Eve) maintaning their celestial meaning? If Milton could link Heaven to the topoi of the pagan pastoral poetry, why not link Heaven to the modern landscapes, to spatial fragments of our lives?

The understanding of Paradise spans between two extremes: a) a spiritual realm, of exquisite harmonies and ethereal perfumes, b) a land of abundance, of leisure and delight. The understanding of Hell, having exhibited different nuances, is also reducible to two main directions:

Harshly symplifying, we can distinguish an indulgent, allegorical and universalist direction, and a rigorous, realistic and selective direction, closer to the popular conceptions. But between the two directions there are many influences, the same authors adhering now at the first tendence, now at the second. (Minois, 1998: 105)

On the one hand, a state of moral suffering, of metaphorical blaze (penitence), for all humans, but which, for some authors, ends up when all things return to their initial condition, purely spiritual; on the other, a place of physical pains, of eternal chaos, of radical sadisms. More important is the fact that the idea of Hell erodes, the fatalism it once contained wears out little by little. In contrast with the theological Hell, implacable, the popular Hell is as perverse in inventing pains as avoidable. In some stories about Hell from the XIXth century, "the convicted always succeed to leave Hell using different stratagems" (Minois, 1998: 332). In the Romanian literature, Ion Creangă (1837-1889), priest for a period, wrote humoristic stories in which humans subdue devils and put them to different jobs.

\subsection{Graduate Students in Advertising}

The graduate students (31) attending the Consulting and Expertise in Advertising program at the University of Bucharest, Faculty of Letters, answered in October 2017 to the 15 questions of a questionnaire meant to bring to light: their most important sources of information about angels, devils, Heaven, and Hell; - the rhythm of their exposure to this information; - the main content of this information; their participation to the social circulation of the knowledge about angels, devils, Heaven, and Hell; - their memories about commercial messages using the four themes; - the most frequent promises, in their opinion, made by commercial messages where the four themes appear; - the expressive potential of the advertisements and commercials using the four elements of the Christian faith, in their opinion.

Most of the questions intended to obtain a contextual 
image of their representations of angels, devils, Heaven, and Hell; this image could increase the consistency of the answers to questions tracking the presence of religious elements in advertising.

The main suppliers of information on angels, devils, Heaven, and Hell are the family, the church and the school (class of religion). In the family, parents and grandparents are mentioned together 10 times, the grandparents: 7 times; the grandmother and the mother are mentioned 2 times, respectively once. The grandfather, the father or only the parents: never. The graduate students declared that grandparents and parents had talked to them rather rarely or accidentally about the other world: 23 mentions. Six respondents stated that they were told about the themes constantly or frequently.

The angels', devils', Heaven's and Hell's features that the graduate students remind from their grandparents' and parents' stories are not very impressive. Heaven welcomes "the good persons", "the bad ones" go to Hell (17); the angels protect, the devils torture; Heaven is the destination of persons who leave our world (1). One goes to Heaven for his or her good deeds and for his or her confessions before the priest (2); everybody has a guardian angel (1), everybody has on his or her shoulders a good angel and a bad angel (5). Four students did not answer the question.

The most cited source of information (15 times) was the church; the school (class of religion): 8 times. Movies, plays, novels were mentioned 9 times, mass media: 7 times, advertising and friends: 4 times (the respondents could indicate as many sources as they wanted).

Heaven would be situated in the sky, Hell: under the earth (16); several pairs of terms express the same polarization: up / down (1), universe superior to Earth / dark places, universe inferior to Earth (1), where God lives / where the Bad lives (1), where there is faith / where malefic forces reign (1); some spiritualizing answers: Heaven and Hell "do not occupy a physical space" (1), they are "states of your soul" (1).

God takes care of the way things go in Heaven (2), with the angels (24) or with Christ (1); Satan manages things in Hell; Lucifer is mentioned also; the devils lend a hand (a "devilish Mafia" is mentioned once). Heaven knows an eternal summer, a total harmony, a divine music, brings peace of mind; in Hell: pains, suffering, torture, cauldrons with pitch, unbearable heat (24). An answer mentioned the oposition between recreation and hard work (the answers pretending to be humorous express an attitude toward the subject).

Angels and devils were made by God (20). In other answers, devils were made by Satan (1) or the creator of devils is unknown (1). Three respondents do not write anything, two declare not having ever thought at the matter.

Angels were made in order to help the humankind (13), to separate good from bad (4); seven students do not write anything, six have never thought at this matter. How were made the angels and the devils? 11 respondents ignore the question, 10 confess they have never reflected on such a topic. The angels and devils were made of light, and the devils are fallen angels (3); a poetical answer: God made the angels blowing up the clouds and bestowing them shape, the devils are angels bathed in pitch. Angels and devils were made at the begining of the world, in the week of Genesis (8), before humans were made (1), after the original $\sin (1)$; the most do not write anything (12); to 7 , that matter was unknown. The place where angels and devils were created? 23 neither offered an answer (11), nor experienced such a thought (12); in Heaven, said 6 of the students.

The angels have wings (7); they "look like us, but have wings" (1); they are childlike, have blue eyes and fair hair, wear nimbus (only two mentioned the nimbus); their skin is white (6), their body is "nice" (1). Innocence, peacefulness, justice, good-heartedness, protection, charity, sincerity, gentleness define them; they are "hovering around beings" (1). They can be "gentle or severe" (1), have feelings as humans do (1). The devils are equiped with horns, hooves, tails, claws, have black wings and red or black skin; they are malicious, merciless, sadic, their laughing is sarcastic and defiant; they "can take the most attractive forms in order to lure" (1), they are like "children prone to bad things" (1).

Angels protect humans from bad things, show them how to accomplish good deeds; the evils teach us to disregard divinity, lure men and women and then torture the sinners.

The angels make the respondents think to their grandparents, to death and to the end of the world, to "beautiful and good beings", to "the smell of cakes", to peace of mind and protection; there are not many those who have never adopted a position concerning angels and devils (3). The devils guide thoughts toward temptation and punishment, to sin and wickedness, to slyness, to sarcasm and black humour, to wrath and suspicion, to stupid things and nervousness; they are linked to "creative madness" and to "attractiveness".

People rarely mention angels, think the respondents; "I don't cite them too soon", declares one; most of them state nothing in this regard. One invokes devils when nervous or when wanting to offend. The most frequent use concerns comparisons: "beautiful as an angel" "a devilish child"...

Twelve respondents did not remember any advertisement with angels, devils, Heaven, or Hell. The advertisement for Philadelphia, a cream cheese qualified as fluffy as the clouds upon which live the angels, was cited by 5 students; several messages (for Raffaelo, chocolates (2), for Axe - angels that fall from the sky when smelling the desodorant (3), for Angel, the perfume from Thierry Mugler (2), for Meda - two she-angels promise Victor to fulfil every wish concerning the salami (2), for Kandia, chocolate (angelic state for milk chocolate, demonic state for dark chocolate (1)) had very few mentions.

The use of angels, devils, Heaven, and Hell can indicate 
the highest intensity of a quality (satisfaction, harmony, purity, security, intelligence, vivacity, seduction, rebellion, adventure); and also "an impetuous, unstoppable desire", "a satisfaction after a pleasure once considered forbidden"; Heaven is a "place where everything is as you want them to be"; advertisements using Hell "couldn't promise, I think, something a human would want".

What would gain the advertisements if they mentioned or used images of angels, devils, Heaven, or Hell? Eight respondents had no statement; 5 considered that these themes attract people's attention (especially because they are rarely used); to treat humorously the religious characters or topoi can help the product (3); this is a sensitive matter, which provokes discussions and demands a judgment (2); these are cultural themes, which help the addressees to ameliorate the image they have of themselves (2).

The following comments must be considered carefully: there were not many respondents, they pertain to a specific socio-professional environment. Even in this case, it is easy to see that the graduate students' information on angels, devils, Heaven, and Hell are blankish and vague. Information to be considered close to traditional mentality come from generations that disappear (grandparents), from institutions ever less valued (school) and more fragmented (mass media). The information coming from friends can be most easily moulded; the meanings even risk to become contradictory; would young people like to fantasize on themes like those which interest us? The few amount of advertisements with angels, devils, Heaven, and Hell diminishes the posibility for students to see them (cf. the frequence of commercial messages diffusion) or to remember them (cf. the studies on the critical amount of exposures to a commercial message for its recollection (Cannon, Riordan, 1994)); but to see them means to have much chances to recollect them: these themes are cultural and provoking. The way the graduate students consider the profits to have by using angels, devils, Heaven, and Hell in advertising differs unsignificantly from the way advertisers themselves see it (we can identify the latter way from their advertisements).

The fact that in too many cases the answers to questions lacked and that the students declared they had not thought about matters mentioned in the questions is significant for me. Their weak information on angels, devils, Heaven, and Hell can attract their indifference toward, even their adhesion to, processes that give these themes new meanings sufficiently remote of those consecrated to produce new cultural-semantic identities.

\subsection{Collected Advertisements}

Initially considered as having neither age, nor sex, angels have been lately anthropomorphized mainly as women and children, beings of delicate beauty. The wings have remained their only characteristic feature. From here to start a process of angelization by simply equipping whatever object of the operation with a pair of wings is only a step. Advertising has made it. We have seen, when discussing about devils, that combining characteristics of two beings leads to a new one: Groupe $\mu$ called interpenetration this operation; most often, the wings are added to women with a considerable capacity of sexual stimulation (beauty as harmony of physical traits is the bridge from spiritual serenity to erotic attraction). Victoria's Secret, brand of underwear for women, wrapped in angel's wings a crouched model (Reichert, 2003: 193). Without other clothes, the model is looking upward: a gaze that searches for an as clear as possible intention in the man's gaze toward her (the headline of the advertisement is Experience heaven on earth - heaven is written with italics; here is another reduction, of the meaning of a topos: Heaven as place of physical pleasures).

Thierry Mugler makes a fragrance called Angel (FIG.1). The very name of the perfume tells us what we will see in the image; needless, given this name, to attach wings to the female body. The bottle, near the woman, evokes a meteorite (fallen from space, too). Its cut sides remind us a crystal. The bottle's nuances of silvery blue are repeated on the woman's dress and on the sand. The visual field is bathed in celestial light. The position of the body and the rich hair, in bronze tones (see the angels of Sotirios stin Chora, Istanbul), evoke the angels. Fallen angels.

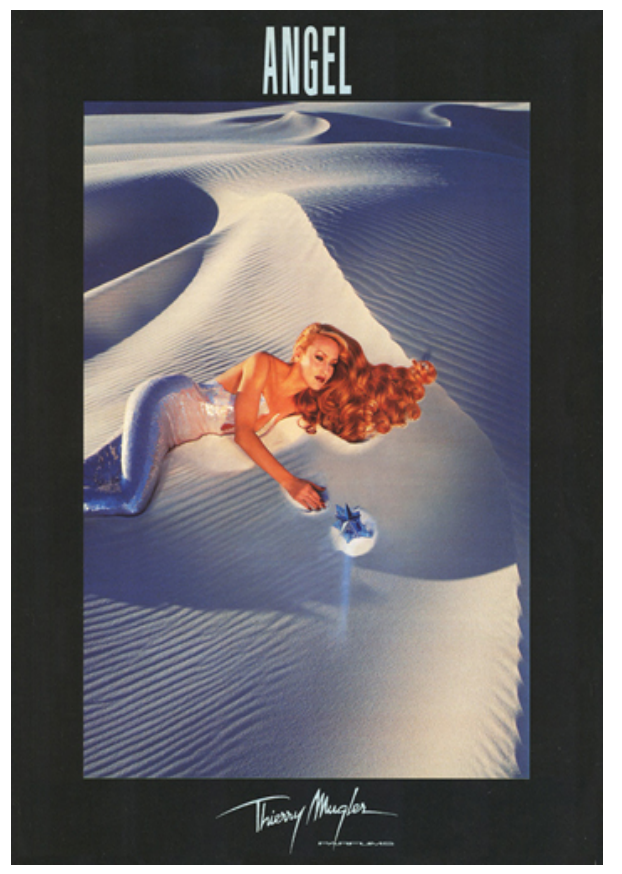

Figure 1. Angel, fragrance by Thierry Mugler

In the same period, another variant, very different: the she-angel is photographed in a balcony, at a high storey of a skyscraper; the whole city is below, very far. Méfiez-vous des anges (Beware of angels), says the headline (FIG.2). The woman is beautiful; beauty, as we know, is a trap, it lures; and the title seems to make her even more beautiful. In 2005, the same point of view: the woman in a high position, the city: far below; now the woman's legs are 
uncovered. She seems to float upon the city's skyscrapers; she keeps in her hands the bottle, which reminds a crystal coming from the celestial spaces' purity. The headline is $A$ perfume captured in a star (FIG.3). The height is not necessarily a sign of angelness; it is confirmed as such by another sign: the name of the fragrance. In an advertisement of 2012, the perfume is endorsed by Eva Mendes (FIG.4); hard to believe in her angelness. The celestial lights are suggested by bright lines whose colours were sufficiently saturated to become electric. In 2015, the woman keeps in her arms a huge bottle having the shape of a star (which has come down from the skies). Beware of angels, again.

For Angel, advertisers make easy-to-recognize selections of the angelness' characteristic features: the most frequently they select beauty, but they deviate it toward temptation (sexuality). Then, they indicate a (quasi-)vertical descendent mouvement. Small bright areas lost in dark backgrounds substitute the celestial shinings.

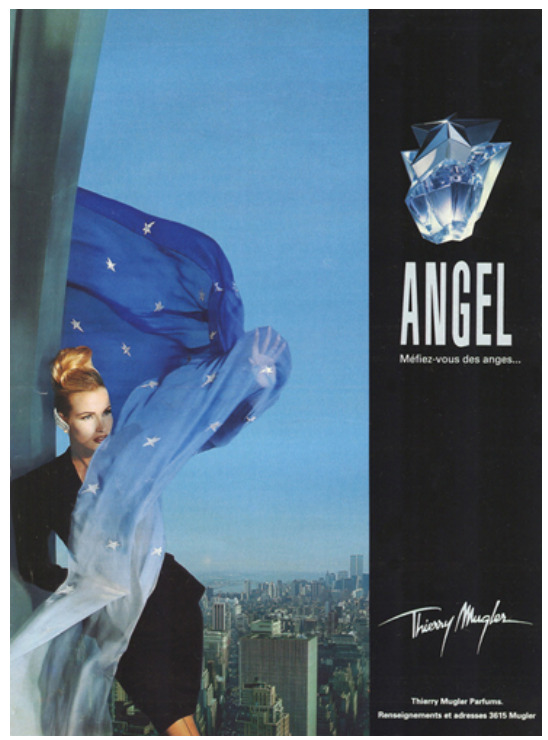

Figure 2. Angel : Beware of angels

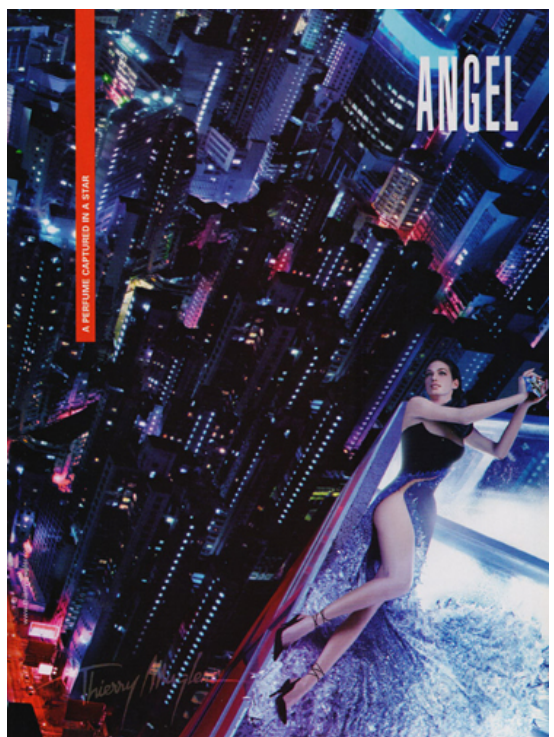

Figure 3. Angel : A perfume captured in a star

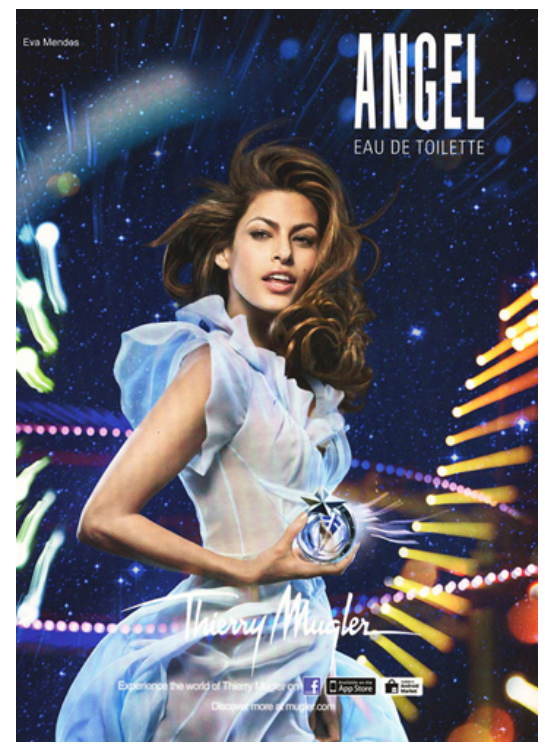

Figure 4. Angel : Eva Mendes as an angel

In the advertisements presented, women are promised an elevation by the product to the angelic condition. But the opposite movement too exists in advertising (showing how plastic is here the moulding of meanings): in some advertisements, the angels fall - toward the human condition, not toward devilness. A series of advertisements for Axe tell us that, excited by the irresistible smell, even angels will fall; the erotic stimulus does not leave them without an answer. It means that the product helps different persons (men) placed on a certain level of being-ness to conquer persons (women) with a superior being-ness, forcing them to fall; the advertisement reveals their attraction for sensorial pleasure. The angel from FIG.5 has a twisted nimbus. The fall changed its cause.

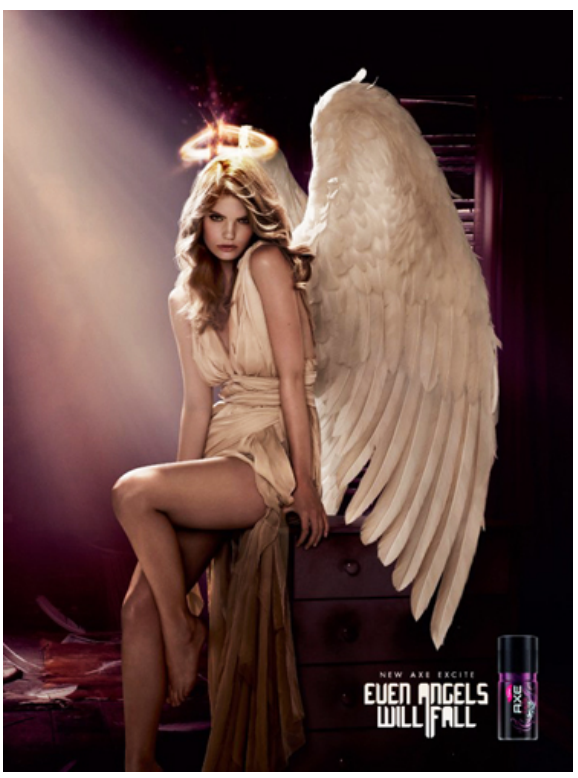

Figure 5. Axe : Even angels will fall

In the devils' roles appear in advertisements beautiful 
human beings (men or women). We have seen that the devils are either beings of great beauty (easy to explain: they are angels, even fallen), or hideous, their descent on the existential ladder being indicated by organic components taken from inferior beings (horns, tail, claws, etc.). Few people acknowledge the devils' first appearance, so their beauty seems nowadays an oddity, a deflection. We infer devilish psycho-spiritual features attributed to these beings (for example, the proness to lure, the cultivation of hidden meanings, etc., all of them revealed with, and this is another characteristic, striking intensity) from substitutes of those components: bottles of alcoholic beverages (FIG.6), curled locks of hair, etc. instead of horns...

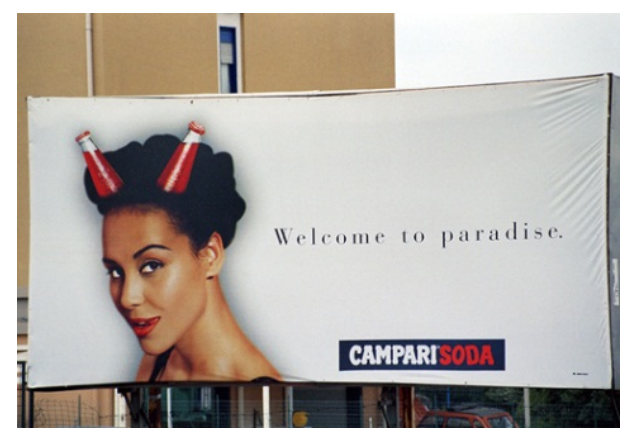

Figure 6. Campari : Welcome to paradise

The change of the initial characteristics (which suggested the devils' perseverance in moving away the humans from the divine grace) augment the devils' numbers, increases the devilish manifestations: as long as they are not anymore dangerous, they can multiply. If in the medieval art the sense of the monstruous aspect, and character, of devils was the sin's horror and the need for radical expiation, in advertisements the significance of the visual (and ideological) reconstruction of devilness is the benefit of an amelioration: our feeling of life is stronger (living becomes more intense). The devil-woman from the advertisement for Campari promises pleasure, enough pleasure to anticipate it by licking your lips. A campaign for Smirnoff launched in 1994 and having as big idea the statement ,Smirnoff vodka helps you perceive the world in unexpected, pleasant ways" presented an advertisement where an old, bearded rocker (black leather jacket, black bandana, etc.) had found his place in a line of angels (FIG.7).

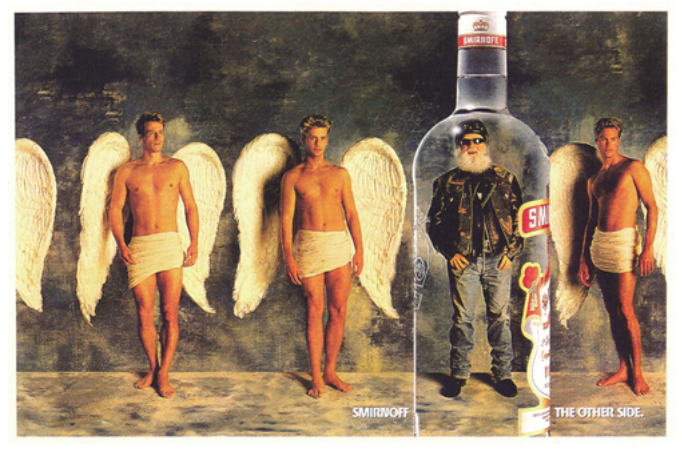

Figure 7. Smirnoff : The other side
In those advertisements for Smirnoff, the modified form (most frequently, the initial forms lay aside, for comparison) is seen through a bottle of vodka: man in tailcoat with pinguins, helicopters near wasps, etc. Our advertisement (FIG.7) suggests that the angelic world is repetitive, predictable, banal, dull, that therefore the very idea of devilness increases the existence's consistency. The rocker does not have horns; his devilness is proved by the angels who stand near him, then by the differences of age and clothing.

So, the devils in advertisements are composite: little horned beings of extraordinary beauty; this combination is unacceptable without a desacralizing reconsideration of every element's meanings. If our systems of expectations integrated into codes value what once was considered as blameworthy, then the combination of beautiful bodies and little horns signals something enough intense to deserve our qualification as sinful and our attention as extra-ordinary; to fix everybody a pair of little horns is more than to recognize a sinner in everbody, is also to devaluate $\sin$.

In some situations, one needs to qualify by a word a form within an image in order to create evidence for a meaning in the respective form that is not easy to notice. Antonio Banderas wears a black t-shirt, throws frowning sights, is placed by the photographer to such a small visual distance from the beholder that he seems to "rush into his / her eyes"... but these elements can be said to convey an intended meaning (devilness) only with the help of a word: the perfume's qualifying name is Diavolo.

Devilness can characterize objects too, cars for example. In the image of an advertisement for Leon $20 \mathrm{v} T$ made by SEAT (FIG.8), the shadow of the car parked near a wall has horns and tail. The headline tells us that the car has a "supernatural power", the copy that the car is "a force which thrills you at first sight". If the car's shadow, and not the car itself, has tail and horns, can we consider the car a devil's appearance (see supra)? The author of the copy felt he / she had to calm us down: the car's power is "controllable".

We deal with some well defined rhetorical operations: combination of features pertaining to two distinct entities (human, angel) into a new visual entity (Axe); substitution of an element in a homogeneous series by an alien element, the perceived element evoking the conceived one (eliminated) and inviting to their comparison (Absolut); association of several visual elements and their qualification by a lexeme which gives them an unexpected meaning (Banderas)... These operations accomplish precise intentions: to produce changes in the meanings of the elements taken into account. Hence, to add wings to a woman's body is not so much to attribute her the qualities of an angel, as to intensify until the superlative a quality of hers, the beauty with erotic dimension. These intentions are linked to systems of values / expectations which society adopts at a certain moment (and which, in time, can live 
many changes).

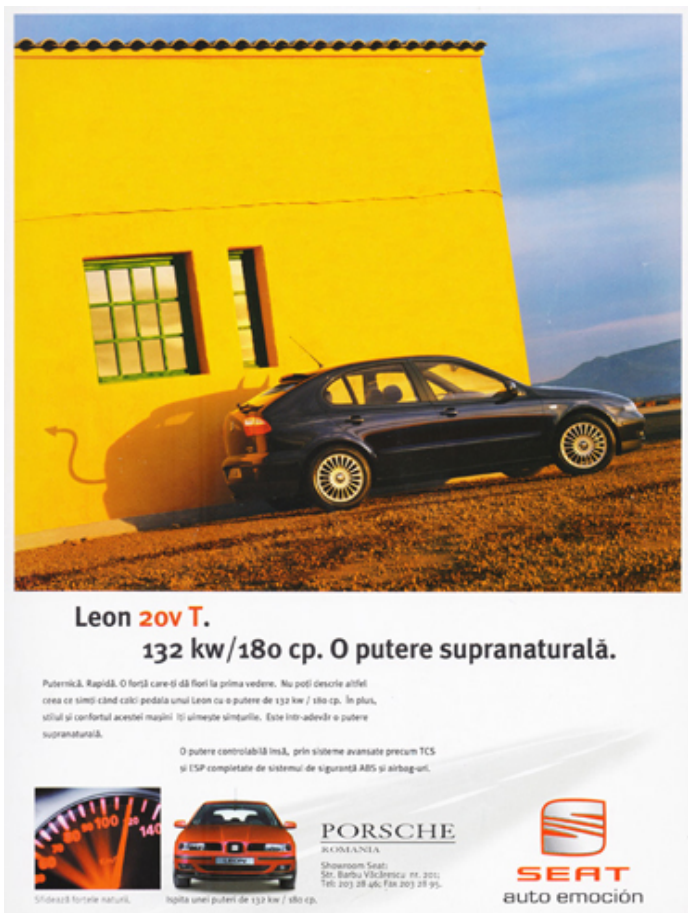

Figure 8. SEAT Leon20v T, a supernatural power

From a place where humans can get an eternal beatitude, Heaven becomes a place "flowing with milk and honey", a land of cockaigne (see Peter Bruegel the Elder, The Land of Cockaigne) or a place of continuously renewed and increased pleasures, sensorial, but with spiritual hints. For Sir Walter Raleigh, the New World was an El Dorado where men anointed their naked bodies with oil, covered themselves with gold dust, and cavorted in drunken ecstasy for six or seven days at a stretch. This was a far cry from God's New Israel; it was closer to the sensual exuberance of Carnival. (Jackson Lears, 1994: 33)

An advertisement for Lux (headline: Heaven can wait) shows a woman in a tub, in the middle of an imperial bathroom (FIG.9). Her eyes are closed; it is well known, above certain intensities, pleasure slows down, even blocks, motricity (expression of a functional materiality). The body seems paralyzed; its separation from the real world is preferentially expressed by the eye closing. The intensity of pleasure can move the person who experiences it on a superior level of being-ness, places him / her toward the "center".

Advertising has not invaded a territory where nobody ventured previously; it seems that it has waited that the reproduction mentioned by Eliade become, as he said, "mechanical". And it tells us a) that thanks to products the road to the center (= paradise) is effortless (to use a Lux soap is enough to enter Heaven) and b) that the Paradise infallibly guarantees the installation in a superior condition (signalized in the advertisement for Lux by the paralysing pleasure).

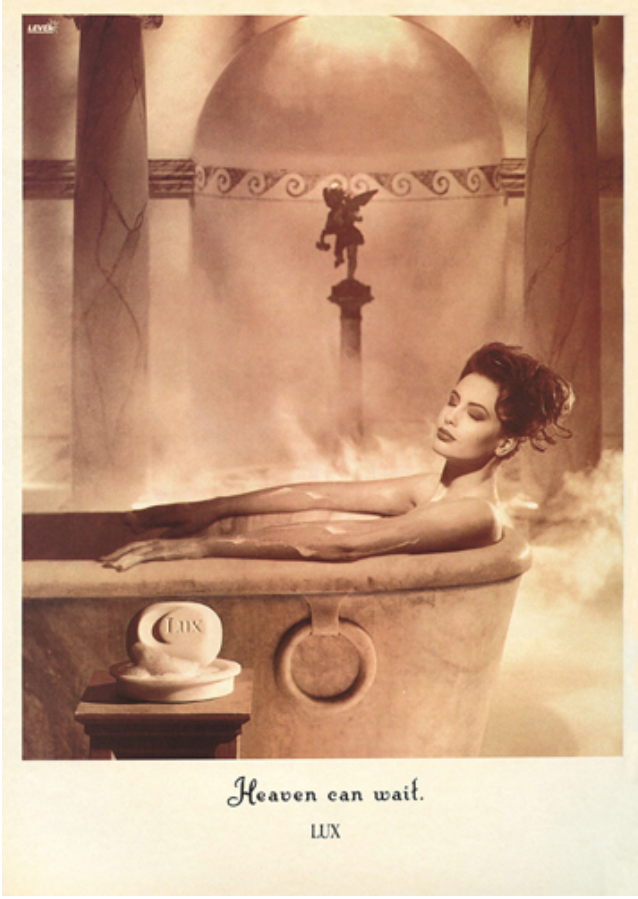

Figure 9. Lux : Heaven can wait

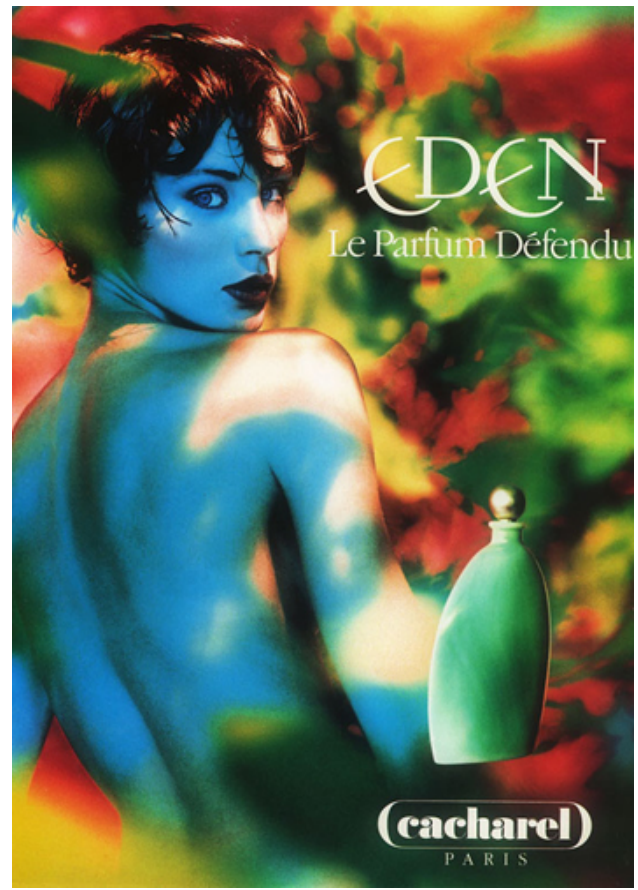

Figure 10. Eden, the forbidden perfume

An advertisement for Eden, fragrance from Cacharel (FIG.10), shows a woman (Eve) turning around toward the beholder, on a bright colourful background. The headline is Eden. Le parfum défendu (Eden. The forbidden perfume). Perhaps Eve looks for Adam: will he finally come? We know that Adam and Eve were chased from Heaven after having violated the taboo; and that humans violate taboos, too; do we have to understand from that advertisement that the very violation of the taboo leads to Heaven? Has Eve 
already used the perfume? Etc. (Usually, in the academic texts interested in advertisements for fragrance the messages are commented in a minimal way and, perhaps, with many reserves. I think this attitude will keep us far from the semantic and expressive richness of these commercial messages. Interpretations are needed. Danesi (2006: 73-75) reviewed four interpretations of an advertisement (Coco. L'esprit de Chanel), I proposed another one. The diversity of interpretations shows the semantic richness of the messages and invites the beholders to elaborate their own judgments.)

In an advertisement for Get 27 (FIG.11) with the headline Get 27. C'est l'enfer (Get 27. It's Hell), a man and a woman (she keeps a glass of liqueur in her hand) are lying down embraced, smiling and with eyes closed; behind them, a quasi-immaterial landscape (water, sky, sailing boats...). Is this Hell? The headline of the advertisement for Get 27 is an irony: we read enfer and we have to understand Paradise; does not irony weaken the first meaning, the strongest, of Hell?

\section{Get 27 c'estl'enfer.}

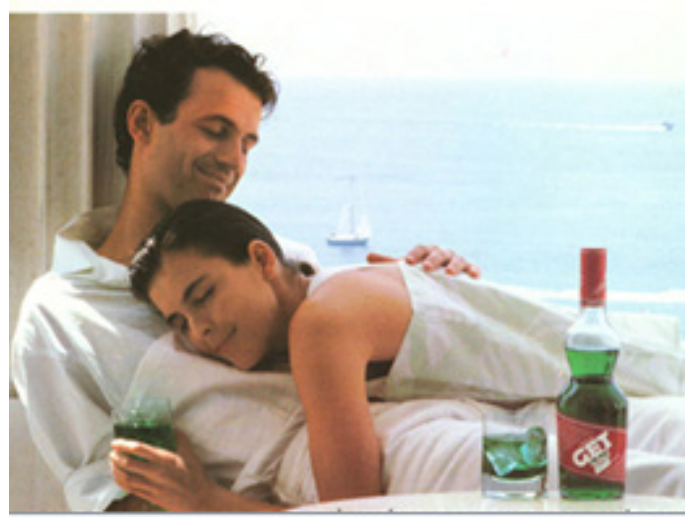

Figure 11. Get 27. It's Hell

The different actualisations of the attributes of Heaven are determined by the functions of products. Usually, we place Heaven in the skies. The vertical orientation suggested by the angels' movement can be exploited in advertisements for cars. The polluting emmissions rise into the atmosphere. Renault expresses its interest for clearer skies by launching models which pollute ever less (in the images, angels are soiled by other cars' emissions). An attribute of Heaven is absolute cleanliness; advertisements for cleaning products (Tide, for example) exalting their efficience show angels using them in order to wash clothes.

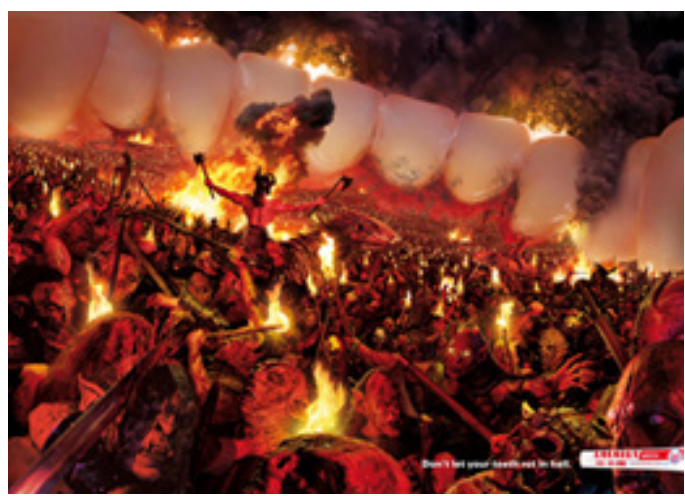

Figure 12. Lacalut : Don't let your teeth rot in Hell

The devils astonish, amaze, hence the idea that they refuse the scheme, the humdrum, the predictable. "The devil symbolizes an illumination superior to common norms, facilitating a gaze more penetrating and reliable, in a manner irreducible to arguments." (Chevalier, Gheerbrant, 1994: 348) He is clever, cultivates the hidden meaning. As for the topoi... Every pleasure having a high intensity qualifies as Heaven the place where it is experienced. Hell is used ironically; or as an instrument of blackmail: Lacalut launched in 2008 an advertisement having for headline Don't let your teeth rot in Hell (FIG.12): behind a wall of teeth (the image places us in the interior of a mouth), a terrible mass of devils, behind the wall: black and hard clouds.

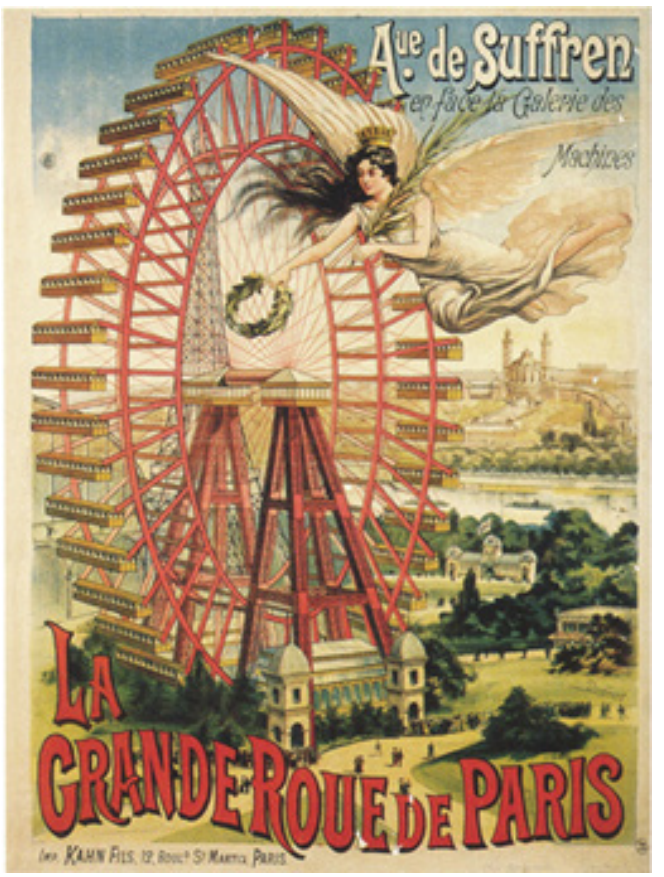

Figure 13. Poster for La Grande Roue de Paris

Angels and devils, Heaven and Hell appeared in advertising at its beginnings (difficult to say what was the rhythm of their appearances). A billboard of 1900 (FIG.13) invites the Parisians to climb in a big wheel (Avenue de Suffren, near the Chaillot Palace). An angel flies close to 
the big wheel with a crown and palma et laurus, probably rewards for the courageous (for the first Christians, the crown of laurels and the branch of the palm were symbols of triumph against the forces of the $\sin$ and of death; then, "by a rather normal extension of sense, the idea of victory is reduced to auguri, wishes of happiness, and chance" (Marrou, 1996: 187)). The angel from the billboard still preserves the traditional features defining angelness.

A billboard of 1906 (FIG.14) made by Leonetto Cappiello recommends an appetizer, Maurin-Quina. It is a green devil who draws the cork from the bottle (green perhaps to evoke the absinthe, metaphorically called la fée verte, the green fairy). The devil reminds us medieval relatives who frightened the sinners; he still preserves its medieval aspect and function.

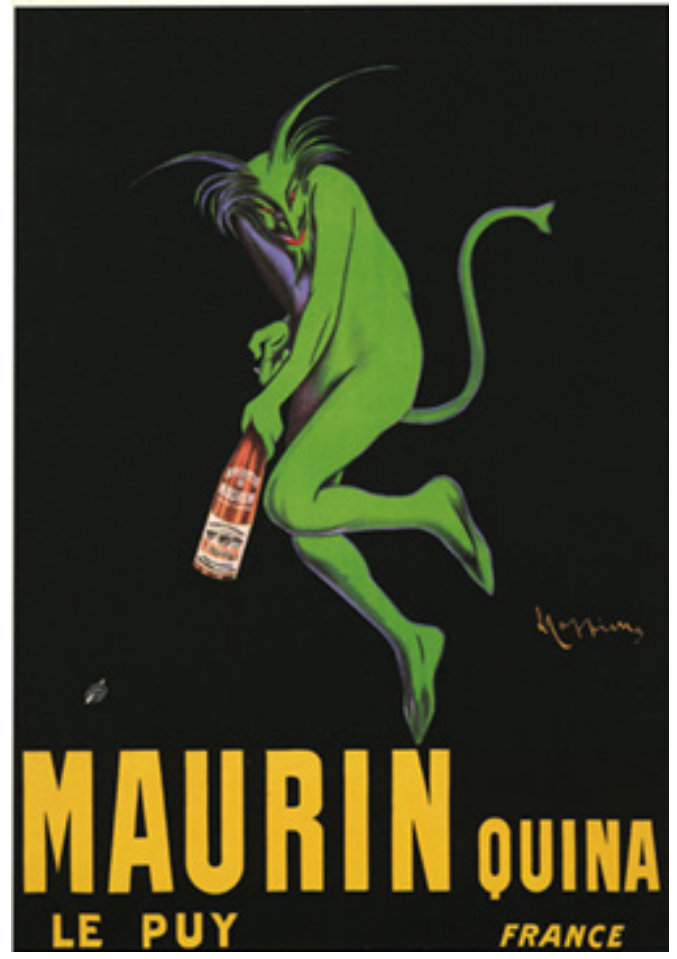

Figure 14. Maurin-Quina, billboard by Cappiello

\section{Discussion: the Use of Christian Faith's Themes by Advertising}

The different ways to understand the other world and the supernatural beings coming from it among humankind have generated ambiguities and hesitations in the very realm of faith. The loss of confience in transcendence has accentuated the process. Minois mentions a series of violent attacks in the XIXth century against Hells: "Lord's creatures destined to eternal suffering, what a barbarity! What an insult to the supreme goodness! Or: "By the dogma of the eternal Hell, theology committed a crime of lese humanity." (quotations in Minois, 1998: 329)
The vague understanding of elements of faith encourages the familiarisation with them. A proof? The easiness with each people propose themselves as angels or devils (Annie Lennox wore wings during a concert, Victoria's Secret presents the new lingerie collections attaching wings to the models...)

This self-proposal that makes a person climb on the ladder of being-ness, in different fields of the popular culture, not only in advertising, is based on simple techniques: interpenetration, for example (a human form is granted a formal feature culturally assigned to another form and, in that very moment, the psycho-moral features linked to it. It is the role of pragmatic elements (contextual, circumstantial (Eco, 1979: 105-108)) to make clear the meaning we have to reserve, on one side, to the formal feature, on the other side, to the form having got the feature; a bull-headed man can be... a bull (as in Zeffirelli's $L a$ Traviata, when the chorus sings Di Madride noi siam matadori and the dancer embodying Piquillo kills five bull-dancers, deed on which the beautiful Andalusian girl conditions her love), the Minotaur, a stupid brute, a cuckold... The way we have to understand wings and (little) horns is clearly supported by the advertising context: it remains to see only if the angels are angels who offer assistance to a human being or human characters whose excellence elevate them to angelness.

To better understand the stakes, we can compare the angels from the advertisements for L'air du temps (Nina Ricci) and Axe. In the first case, the angel in the metro (American shot) wears a white t-shirt not quite clean, her cheeks are dirty (she is pretty, but her eroticism is not stressed); in the second case, the eroticism of the angel photographed in full shot is strongly emphasized (her sex appeal is obvious, she is scantily dressed...). In a way or another, the advertisements create hierarchies between the two combining entities. If in the message for Nina Ricci angelness seems to outrun humanity (a woman could reach a level of excellence which can be called angelness, says the advertisement), in the message for Axe the wings emphasize the excellence of beauty and the nimbus: the falling from the skies, but the stressed eroticism diminishes angelness.

The paradise is a topos of pleasure. The priests say that in Heaven there is no pain, no sorrow, no sigh, but the paradise of advertising presents itself as hedonistic. Many of the pleasures brought up by the products in advertisements where angels or devils appear are physical or prop up spiritualization on a clear physical basis (Lux). The pleasures of the senses are intense and transitory (McGill, 1968: 265-270), that is why advertisements have to find a way to entice people to continuously use products. So, if Heaven can wait (Lux), it means that another one is at hand, immediately. Hence, a convenient inference: if a product leads you to heaven, use it as often as possible. More than that: if a product can lead you to heaven, there are probably many more doing the same thing. 
Its advertisement tells us that Get 27 would lead us in the same place (the irony in enfer used in the headline becomes obvious with the help of the image). This advertisement too can be integrated to the personalized format (Leiss, Kline, Jhally, 1986: 194-210) (the authors identify four formats: product information format, product image format, personalized format and, respectively, lifestyle format, which emphasize the products' material-functional qualities, their symbolic values, the consumers' affective ties with products, and, respectively, the social contexts in which products are used, the social judgments they inspire). It does not seem difficult to investigate what formats fit with the use of angels, devils, Heaven and Hell.

\section{Conclusions}

Different semantic components of sacred entities are used to serve new goals, other components are abandoned. Advertising plays an important part in this refunctionalization. Taking profit of the circulation of so many nuances in faith matters, of the loss of trust in transcendence, of the continuous tendency of popular thinking to move down faith toward its understanting, advertising has given angels, devils, Heaven, and Hell new meanings, commanded by commercial interests.

The advertising industry tries to make audiences intensify by consumption their feeling of existence. In this situation, Heaven and Hell would be just lexicalizations of the fictional territories where I invest my subjective energy: I put my dreams and wishes into words. The cited techniques (certainly, only a part of those used in commercial messages) support this hypothesis; to interpenetration (Axe), to the creation of a series of identical forms in which one is substituted by a form with opposed meanings (Smirnoff), techniques used at the visual level, one has to add techniques that link the linguistic and visual elements of advertisements: irony (Get 27), or the selection in a utterance of a single reading from several available, with the help of the image (Lux) (an atheist, for exemple, could say Heaven can wait; the image reduces the possible readings to that of a hedonist).

We are thus invited to play roles (angel, devil) whose content was modified in order to promise euphoric investments of psychic energy. Would the opponents of advertising be happy to state that the absence of pleasure, that boredom mean Hell? From contrary to Heaven, Hell would become contradictory to it. It seems to become ever emptier of meaning: the absence of pleasure is its single incontestable one. The conclusion is a new hypothesis: if familiarization with sacredness slowly dissolves it and denies its consistency, isn't advertising becoming more dangerous for religion than the evolutionary theory or the atheism?

\section{REFERENCES}

[1] BELCH, George E., BELCH, Michael A., 2007, Advertising and promotion. An integrated comunications perspective, Boston / Burr Ridge IL, McGraw-Hill / Irwin

[2] BOUYER, L., 1950, Le sens de la vie monastique, Turnhout, Brepols

[3] CANNON, Hugh McKinley, RIORDAN, Edward A., 1994, „Effective reach and frequency: do they really make sense?“", Journal of Advertising Research, march-april, p.19-28

[4] (https://www.researchgate.net/publication/258311203_Effe ctive_Reach_and_Frequency_Do_They_Really_Make_Sen se)

[5] CHEVALIER, Jean, GHEERBRANT, Alain, 1994, Dictionnaire des symboles, Paris, Laffont / Jupiter

[6] COTTIN, Jérôme, WALBAUM, Rémi, 1997, Dieu et la pub, Paris, Editions du Cerf

[7] DANESI, Marcel, 2006, Brands, New York, Routledge

[8] DELUMEAU, Jean, 1997, Grădina desfătărilor. O istorie a paradisului, trad.rom., București, Humanitas

[9] ECO, Umberto, 1979, A theory of semiotics, Bloomington, Indiana University Press

[10] ELIADE, Mircea, 1993, Aspects du mythe, Paris, Gallimard

[11] ELIADE, Mircea, 1968, Traité d'histoire des religions, Paris, Payot

[12] Groupe $\mu, 1992$, Traité du signe visuel, Paris, Seuil

[13] LEARS, Jackson, 1994, Fables of abundance. A cultural history of advertising in America, New York, Basic Books

[14] LEISS, William, KLINE, Stephen, JHALLY, Sut, 1986, Social communication in advertising, Toronto, Methuen

[15] MAGUIRE, B., WEATHERBY, G. A., 1998, "The Secularization of Religion and Television Commercials", în Sociology of Religion, 59, 2, p.171-1781

[16] MALLIA, Karen L., "From the sacred to the profane: A critical analysis of the changing nature of religion imagery in advertising", in Journal of Media and Religion, 8, 3, p. $172-190$

[17] MANGO, Cyril, 1998, La civiltà bizantina, trad.it., Roma-Bari, Laterza

[18] MARROU, Henri-Irénée, 1996, "Palma et laurus“, în Patristică și umanism, trad.rom., Bucureşti, Meridiane, p.179-200

[19] MARROU, Henri-Irénée, 1996, “Un înger decăzut, un înger totuși“،, în Patristică și umanism, trad.rom., Bucureşti, Meridiane, p.495-515

[20] McGILL, V. J., 1968, The idea of happiness, New York, Frederick A. Praeger

[21] MINOIS, Georges, 1998, Istoria infernurilor, trad.rom., Bucureşti, Humanitas

[22] MOORE, Rick Clifton, 2005, "Spirituality that sells: religious imagery in magazine advertising", in Advertising 
and society review, $6,1 \mathrm{https}: / /$ muse.jhu.edu/article/184.211 (access provided by the University of California Berkeley)

[23] NARDELLA, Carlo, 2012, "Religious symbols in Italian advertising: symbolic appropriation and the management of consent", Journal of contemporary religion, 27, 2, p. $217-240$

[24] PLEȘU, Andrei, 2003, Despre îngeri, Bucureşti, Humanitas

[25] REICHERT, Tom, 2003, The erotic history of advertising, New York, Prometheus

[26] WEATHERBY, Georgie Ann, PUGH, Jean, 2008, "The secularization of religion and televison commercials in the US: an update", Sociology, social work and social welfare, vol.2, issue 1 